Shorobura I. M. Peculiarities of state-public school management. Journal of Education, Health and Sport. 2022;12(1):331-343. eISSN 2391-8306. DOI http://dx.doi.org/10.12775/JEHS.2022.12.01.028

The journal has had 40 points in Ministry of Education and Science of Poland parametric evaluation. Annex to the announcement of the Minister of Education and Science of December 1, 2021. No. 32343. Has a Journal's Unique Identifier: 201159. Scientific disciplines assigned: Physical Culture Sciences (Field of Medical sciences and health sciences); Health Sciences (Field of Medical Sciences and Health Sciences).

Punkty Ministerialne z 2019 - aktualny rok 40 punktów. Zalącznik do komunikatu Ministra Edukacji i Nauki z dnia 1 grudnia 2021 r. Lp. 32343. Posiada Unikatowy Identyfikator Czasopisma: 201159. Przypisane dyscypliny naukowe:Nauki o kulturze fizycznej (Dziedzina nauk medycznych i nauk o zdrowiu); Nauki o zdrowiu (Dziedzina nauk medycznych i nauk o zdrowiu).

(1) The Authors 2022;

This article is published with open access at Licensee Open Journal Systems of Nicolaus Copernicus University in Torun, Poland

Open Access. This article is distributed under the terms of the Creative Commons Attribution Noncommercial License which permits any noncommercial use, distribution, and reproduction in any medium,

provided the original author (s) and source are credited. This is an open access article licensed under the terms of the Creative Commons Attribution Non commercial license Share alike.
(http://creativecommons.org/icenses/by-nc-sa/4.0/) which permits unrestricted, non commercial use, distribution and reproduction in any medium, provided the work is properly cited.

The authors declare that there is no conflict of interests regarding the publication of this paper.

Received: 15.12.2021. Revised: 25.12.2021. Accepted: 31.01.2022.

UDC 378.016:373.3.014.611

\title{
PECULIARITIES OF STATE-PUBLIC SCHOOL MANAGEMENT
}

\section{M. Shorobura}

\section{Khmelnytskyi Humanitarian-Pedagogical Academy, Khmelnytskyi, Ukraine}

Shorobura I.M., Doctor of Pedagogical Sciences, Professor, Rector, orcid.org/0000-0003-3728-7968

\section{Abstract}

The article analyzes the features of public administration of the school. Today, a school cannot exist separately from the needs and interests of the community, but it can be a driver of its development and implementation. In this case, the model of a socially active school can be effective, which aims not only to provide educational services to students, but also to develop the community, involve parents and community members in solving social and other problems that exist in the school. and in the community. The management of socially active schools is based on partnership and volunteer relations, namely the management is carried out on the basic principles of: democracy; prognosticity; adaptability; flexibility and mobility; focus on development, innovation, creativity; personality-oriented and individual approach.

The model of activity of an educational institution as a socially active school includes three components, namely: democratization; volunteering; mutually beneficial partnership in 
the school-community system, which is implemented through project activities of all participants in the educational process. An important role belongs to the educational district.

The growing influence of parents and the public contributes to the creation of public administration bodies, namely the School Board, the Board of Trustees, the Public School Fund, and the Alumni Association. Public authorities of the school consider strategic issues of school development and exercise public control. In the formation of the model of public administration of educational institutions of great importance should be given to work with parents of students. Today, public school bodies are being actively created. They approve strategic development plans, have the opportunity to exercise public control over its work.

Key words: public administration; public administration bodies; public active school.

\section{ОСОБЛИВОСТІ ДЕРЖАВНО-ГРОМАДСЬКОГО УПРАВЛІННЯ ШКОЛОЮ}

\section{I. М. Шоробура}

Шоробура Інна Михайлівна - доктор педагогічних наук, професор, ректор Хмельницької гуманітарно-педагогічної академії. shorobura@gmail.com orcid.org/0000-0003-3728-7968

В статті проаналізовано особливості державно-громадського управління школою. Сьогодні школа не може існувати окремо від потреб та інтересів громади, але може бути рушієм іiї розвитку та реалізації. Дієвою у такому випадку може бути модель громадсько-активної школи, яка ставить перед собою за мету не лише надавати учням освітні послуги, а й розвивати громаду, залучати батьків і мешканців громади до розв'язку соціальних та інших проблем, які існують і у школі, і в громаді. В основі управління громадсько-активними школами лежать партнерські та волонтерські відносини, а саме управління здійснюється на основні принципів: демократичності; прогностичності; адаптивності; гнучкості та мобільності; орієнтації на розвиток, інноваційність, творчість; особистісно зорієнтованої спрямованості та індивідуального підходу.

Модель діяльності закладу освіти як громадсько-активної школи включає три складові, а саме: демократизацію; волонтерство; взаємовигідне партнерство в системі «школа-громада», що реалізується через проектну діяльність усіх учасників освітнього процесу. Важлива роль належить освітньому округу. 
Зростання впливу батьків та громадськості сприяє створенню громадськодержавних органів управління, а саме Ради школи, Піклувальної ради, Громадського шкільного фонду, Асоціації випускників. Громадсько-державні органи управління школою розглядають стратегічні питання розвитку школи та здійснюють громадський контроль. У формуванні моделі державно-громадського управління закладом освіти великого значення слід надати роботі з батьками учнів. Сьогодні активно створюються громадсько-державні органи управління школою. Саме вони затверджують стратегічні плани розвитку, мають можливість здійснювати громадський контроль за ії роботою.

Ключові слова: державно-громадського управління; громадсько-державні органи управління; громадсько-активна школа.

The statement of the problem... The transition from state educational management to state-public one primarily requires the creation of an effective management model that would change the formal, superficial attitude of the public to the process of its development to constructive one [2]. The new management model must be democratic and open. It should take into account public opinion, which leads to changes in the functions and structure of central and regional management [10].

Analysis of previous research and publications... Problems of improving school management are revealed in the works of V. Maslov, L. Danylenko, N. Ostroverkhova, Y. Konarzhevsky. The researches of V. Grabovsky, G. Dmitrenko, G. Yelnikova, O. Zaichenko, V. Knyazev, M. Komarnytsky, V. Maslov, R. Pastushenko, G. Polyakova, T. Shamova and others reveal the features of state-public school management.

The aim of the study The purpose of this article is to analyze the features of statepublic school management.

Main body The Law of Ukraine «On Education» claims that state-public school management in the field of education is the interaction of public authorities, local government with public associations and other civil society institutions in order to make effective management decisions and meet public interests in education. To implement this form of management, representative public associations and other civil society institutions are created, which may be represented by: pedagogical, teaching and scientific staff; students; parents; educational institutions; employers and various associations of these categories [7]. A modern general secondary education institution should provide students not only with certain knowledge and skills, but also with a socially adapted and socially oriented generation [4]. 
Nowadays a school cannot exist separately from the needs and interests of the community, but it can be a driver of its development and implementation. In this case, the model of a socially active school can be effective, which aims not only to provide educational services to students, but also to develop the community, involve parents and community members in solving social and other problems that exist in the school. and in the community [1]. The use of the model of socially active school does not separate students from real life, but actively includes them in educational activities, creates a single field of civic education for all participants of educational process [4].

Socially active school is an educational institution that involves the community to ensure the urgent and long-term goals of the school and the community. The most valuable are partnerships and public self-organization, and self-government development. This is a special innovative model of educational institutions' system development, which is based on the transformation of the educational institution into a community center; focus on the child's personality; formation of a learner's active life position; respect for the rights and freedoms of everyone; educating the younger generation as subjects of democracy [4].

The management of socially active schools is based on partnership and volunteer relations, namely management is carried out on the basic principles of democracy; prognosticity; adaptability; flexibility and mobility; development orientation, innovation, creativity; personality-oriented and individual approaches [2].

The model of an educational institution as a socially active school includes three components: democratization; volunteering; mutually beneficial partnership in the «schoolcommunity» system, which is implemented through project activities of all participants of educational process.

The development of a real educational district development program is an important task for the district council and should be based on the state educational regulatory framework, ideas of science, best practices and self-initiative with anticipation of expected intermediate and final results in developing individual abilities of every child in the district, the trajectory of her/his personal development [8].

Since the interaction between the state and the community is necessary to enable effective state and public educational institution management, the model of socially active school best ensures this cooperation, as it optimally combines the activities of both management verticals in the interests of man, society and state that helps to realize the main goal of such partnership management [2]. 
Educational district is a set of educational institutions and their branches, including out-of-school education institutions, cultural institutions, physical culture and sports institutions, providing access to education for people living in the area [6].

The network of support schools was created from 2013-2014 to 2016-1017 academic years by reorganizing 485 of educational institutions with a change in their degree [9]. On the $1^{\text {st }}$ of October 2015, 83 educational districts have been created, which include about 300 schools. They covered 40,479 students. They train more than 6,000 teachers [8]. By 2017, according to the Ministry of Education and Science, there are 178 support educational institutions in Ukraine, each of which has branches. Thus, on the $1^{\text {st }}$ of October 2020, the number of support secondary education institutions in Ukraine reached 993.

As practice shows, educational districts have a significant advantage over conventional schools, because they form a consistent, multi-level system of education. By receiving school education at the place of residence, the student has the opportunity to develop individual abilities on the basis of other educational institutions in the district. The main thing is to provide pedagogical support for the personal development of every child, his/her psychological and social formation [1].

The functions of the district council are as follows: development of the district regulations; submission to the education management body suggestions of teaching hours redistribution between educational institutions - subjects of the district, educational process organization, school buses routes, which provide transportation of pupils and teachers to the places of study, work and home, functioning of interlibrary card for temporary redistribution and library funds formation; coordination of educational work of available material base effective application of the subjects of the district for extracurricular, club, breakout groups work, organization of leisure activity for children, pupils, boarders and their families; promoting social, psychological and speech therapy services activities; coordination together with the district (city) scientific-methodological center of methodology work aimed at: organizing the educational and methodological consultations to employees of the district; improving the activities of methodological associations, other structural units of the district; cooperation with higher educational institutions, postgraduate education institutions and cultural institutions; reports on its activities at least once a year, usually at the end of the school year at the general meeting of employees of the district [6].

The educational district council plays an important role in creating a single educational space, shifting the managerial emphasis from individual educational institutions to the district coordinating council. It is a positive example of state and public management, which is based 
on democratic, humanistic, subject-subject principles, interaction and tolerance, openness and transparency [8].

Today there is a transition from state to state-public education management. Along with the body of state authority, public authorities are also being created. Public participation in management contributes to the formation of a creative atmosphere and a positive psychological climate at school. This interaction is based on partnership between the state and the public. Socially active schools are guided by the principles of partnership, volunteering, democratization.

The growing influence of parents and the public contributes to the creation of statepublic authorities, namely the School Board, the Board of Trustees, the Public School Fund, and the Alumni Association. State-public school authorities consider strategic issues of school development and exercise public control.

The Board of Trustees is established in all educational institutions. In addition to the Board of Trustees, the school has other bodies of public self-government. The Board of Trustees interacts with them. In every school there is a need to create a Board of Trustees, that helps to improve the financial, material, human and spiritual potential of the educational institution.

The legal framework of Ukraine provides an opportunity to create a state-public system of school management, public control over the implementation of management decisions in the school.

The school is accountable to the local community. Nowadays, open school reports and public reporting are practiced. The head has to report annually on his/her activities at the teaching staff meeting, parent committee, council, board of trustees and the public. Today it is important to involve public opinion and the public in the management of educational institutions. The main objectives of reporting are: transparency, openness and democratic governance. This creates a positive image of the institution among the public; helps to unite the school and the public.

Today the public is seen as a social partner, public organizations, foundations, associations are created. The community is interested in being the founder, resource manager, coordinator in the development of a modern school. This is the basis of state-public institution management.

Thus, a socially active school is an educational institution in which much attention is paid to the formation of partnerships between the school and all the resources available to the community and the implementation of educational, social and health services. The latter 
include, for example, improving learners' performance, developing the youth movement, and strengthening family and good neighbourly relations between community members.

Nowadays, councils are being established in schools as one of the manifestations of state-public management. The school council is a permanent body of public self-government in the period between conferences. The purpose of the council is to promote democratization and humanization of the educational process; combining the efforts of pedagogical staff and pupils community, parents, the public to develop the school and improve the educational process; formation of a positive image and democratic style of school management; expansion of collegial forms of school management; increasing the role of the public in addressing issues related to the educational process organization [12]. The main tasks of the council are: to increase the efficiency of the educational process in cooperation with the family, the public, public and private institutions; determination of strategic tasks, priority directions of school development and assistance in organizational and pedagogical support of the educational process; formation of healthy lifestyle skills; creating a proper pedagogical climate at school; promoting the spiritual and physical development of pupils and gaining their social experience; support for public initiatives to improve studying and upbringing of pupils, teachers' creative research and experimental work; promoting the organization of leisure and rehabilitation of pupils; initiating actions that would promote strict compliance with the provisions of current legislation on compulsory general secondary education; stimulating moral and material encouragement of pupils, assistance in finding and supporting gifted children; strengthening partnerships between pupils' families and the school in order to ensure the unity of the educational process [12].

The school council operates on the following principles: voluntary and equal membership; democracy, the rule of law and publicity; human rights priority; organizational independence within the limits set by law; collegiality of decision-making; responsibilities to the parent community of the school, teaching staff and pupils community; cooperation with state education management bodies, public organizations and city self-government bodies. Representatives of the teaching staff, pupils of II-III levels of education, parents and the public are elected proportionally to the council [12].

To address current issues, the council may establish permanent or temporary commissions in certain areas of work. The commission members and the content of their work are determined by the council. The commission members have the right to consider all the school issues related to the educational process organization, holding of health and cultural events. 
The School Council acts in accordance with the above tasks and objectives: organizes the implementation of conference decisions; makes proposals to change the type, status, profile of study, study of foreign languages; together with the administration considers and approves the long-term forecasting of the school and monitors its implementation; together with the administration monitors the implementation of the school charter; approves the school mode of operation; approves the working curriculum for each academic year; hears the report of the council chairman, information of the head and his deputies on issues of educational, financial and economic activities etc. The chairman of the School Council supervises the work of the School Council; reports to the school community on the School Council activities during the school year, individually represents the School Council in various institutions and organizations [13].

In the formation of the state-public educational institutions management model, a great importance should be given to work with learners' parents: to study the conditions and level of organization of children's education at home; to promote relationships with single-parent and dysfunctional families and the families in difficult life circumstances; constantly involve parents in their participation in the life of the class, school, educational activities and holding «Open Days» etc.; to organize for parents class meetings, lectures, conversations, methodical consultations; to organize meetings for parents with a psychologist, consultations with doctors, a lawyer, law enforcement agencies; to practice the experience of individual work with parents of unsuccessful, difficult-to-educate pupils, pupils with deviant behavior etc.; to think over joint celebration of birthday days, calendar national and family holidays; to encourage parents to participate in the organization of recreation - joint tourist trips, visits to exhibitions, theaters, evenings, etc.; to organize joint sports holidays and entertainments; to encourage their parents to work together with pupils and teachers; ultimately involve parents in the management of the school and in many other activities.

The leading form of work with parents is the organization of the board of trustees (self-governing body formed of representatives of the executive council, enterprises, institutions, organizations, educational institutions and individuals to establish conditions for effective school work and solve problems related to educational process), class and school parent committees and the involvement of parents in the school council (permanent in the period between the general meeting of the body of public self-government).

It is necessary and interesting to work on establishing cooperation with enterprises, organizations and institutions that belong to the community where the educational institution is located [5]. 
Many schools today have Boards of Trustees that help engage the public in solving school problems. The Board of Trustees is a self-governing body formed of representatives of enterprises, schools, parents, and the public in order to provide favourable conditions for the effective operation of the educational institution. The purpose of the Board of Trustees is to ensure the availability of general secondary education for all citizens, meet the educational needs of the individual, involve the general public in solving problems of education and upbringing. The main tasks of the Board of Trustees are: cooperation with executive bodies, organizations, enterprises, institutions, educational institutions, individual citizens, aimed at improving the conditions of education and upbringing of pupils; assistance in strengthening field, material-technical, cultural-sport and recreational base of the school, the creation of a charitable parent fund; assistance in organizing and conducting activities aimed at protecting the lives and health of participants in the educational process; organization of leisure (competitions, evenings, sports competitions, etc.) and rehabilitation of pupils, teachers; promoting the creation and rational use of compulsory education fund; promoting the implementation of current legislation on compulsory general secondary education; prevention of child neglect, assistance in employment of secondary schools graduates; stimulating the creative work of teachers and pupils; comprehensive strengthening of ties between pupils' families and the school; promoting the social and legal protection of participants in the educational process [11].

The Board of Trustees operates on the following principles: the priority of human rights, the combination of interests of the individual, society; municipality; collegiality of decision-making; voluntary and equal membership; legality, publicity. The Board of Trustees is created by the decision (conference) of the school.

Chairman of the Board of Trustees: convenes and coordinates the work of the Board of Trustees; prepares and conducts meetings, approves decisions of the Board of Trustees; determines the functions of the deputy, secretary and other members; represents the Board of Trustees in institutions, enterprises and organizations on matters within its competence. The chairman of the Board of Trustees has the right to delegate his powers to the members of the Board of Trustees [11].

The Board of Trustees has the right to: submit proposals to the executive authorities, school principals, general meetings (conferences) on strengthening material-technical, field, cultural-sport and recreational base of the secondary school; to promote the attraction of additional sources of funding for secondary education; to promote the attraction of additional sources of funding for secondary education; take measures to strengthen the material- 
technical and educational base; to promote the creative work of teachers and pupils; to take part in the consideration of citizens' appeals on issues related to the work of the general educational institution in order to facilitate their resolution in the prescribed manner [11].

Parent committees work in almost every school. Thus, class parent committees are created in order to provide parents with assistance to the school, class teacher in creating favourable conditions for the development, education and upbringing of children, protection of their rights and interests. Class parent committees are a body of school self-government [13]. The main task of the parent committee of the class is to assist the school and family in the implementation of the Law of Ukraine «On Education», the provisions of the Convention on Child's Rights, Regulations of the Constitution of Ukraine on education.

The main functions of the class parent committee are: to control over the sanitary and hygienic regime and improvement of the class; assistance to the class teacher in the organization of leisure, recreation of children, other types of school activities; identification of socially unprotected children and families who are in a socially dangerous situation, preparation of acts of housing and living conditions inspection of family, providing it with the necessary assistance; assisting the class teacher in organizing work with parents who do not fulfill their parental responsibilities, developing means of social influence on such parents; promotion of positive experience of family upbringing; control over the correct distribution and use of class funds; assisting class teachers in conducting class parent meetings; consideration of other issues of class life [13].

The Regulations prescribe the procedure for forming, composition, structure and organization of the class parent committee. The class parent committee has the right to: make proposals to the principal, the pedagogical council and the general school parent meeting to address organizational and economic issues, extracurricular activities, etc .; hear the report of the principal on the long-term school plan; to protect the legal rights and interests of children; participate in school management; make suggestions to improve the educational process organization, increase its efficiency; participate in a meeting of the general school parent committee; to take an active part in the consideration of applications of parents for financial assistance to children with status; to help the class teacher in the organization of children's leisure, other types of school activities; comply with the Charter of the school in the section on the rights and responsibilities of parents [13]. Class parent committees make decisions in the form of proposals, which are subject to mandatory consideration by school officials with consistent notification of the results of consideration and motivation of decisions [13]. 
The Pedagogical Council also promotes the establishment of state-public management. The Pedagogical Council is a collective body that manages the educational and methodological work of an educational institution. One of the main tasks of the Pedagogical Council is to create a friendly, efficient teaching staff. This is also achieved, among other measures, by the correct selection of issues that are recommended for discussion by the Pedagogical Council. Thus, the discussion of the work plan or report of the methodological commission or one of the teachers at a meeting of the Pedagogical Council is usually of great interest to the whole team; comparing the work of a colleague with his own, everyone tries to use the best experience in their work [14].

The main activities of the Pedagogical Council are: improving the educationaltheoretical and methodological level of teaching; forecasting the development of the educational institution in the future; introduction of new psychological and pedagogical ideas, results of research and experimental and advanced pedagogical experience in practice; consideration of problems of teaching subjects efficiency, quality of pupils' knowledge and skills; problems and structure pupils' national education; on long-term and annual work plans of the educational institution, etc. [14].

The Pedagogical Council should provide two areas of activity: organizational and pedagogical: approval of the work plan, consideration of the work results for a certain period, pupils' graduation and transfer, analysis of the pedagogical process in the educational institution; educational-pedagogical problem and ways of its realization, discussion of research results, best experience approbations. Forms of such activities of the Pedagogical Council are evidence of the teaching staff qualifications[14].

Clear instructions and tasks, content and functions of the council are set out in the Regulations on the Pedagogical Council. The main thing in the work of the Pedagogical Council, especially during training - providing methodological assistance to teachers. The activities of the Pedagogical Council are managed by the principal.

Conclusions Public-state school authorities are being actively created. They approve strategic development plans, have the opportunity to exercise public control over its work. The analysis of qualitative changes in schools in state-public management needs further research.

\section{Список використаних джерел:}

1. Вербило Л.В. Денишевський освітній округ - школа людинотворення. Завучу. Усе для роботи. 2016. №3-4. С. 22-23-22-27 
2. Волченко Л. Модель управління громадсько-активною школою. Державно-громадське управління школою / упоряд. М.К. Голубенко. Київ: Шк. світ.2010. С. 23-35. (Бібліотека «Шкільного світу»).

3. Єльникова Г. Методологічні засади державно-громадського управління загальною середньою освітою. Державно-громадське управління школою / упоряд. М.К. Голубенко. Київ: Шк. світ.2010. С. 5-17. (Бібліотека «Шкільного світу»).

4. Климко Л.В. Розбудова регіональної мережі громадсько-активних шкіл за умов освітніх змін. Управління школою. 2018. №13-15. С. 20-24.

5. Мельничук Л.С. Школа як осередок розвитку громади. Управління школою. 2018. №10-12. С. 73-78

6. Про затвердження Положення про освітній округі опорний заклад освіти: постанова Каб. Міністрів України від 19 червня 2019 p. № 532. URL:https://zakon.rada.gov.ua/laws/show/532-2019-\%D0\%BF\#n78.

7. Про освіту: Закон України від 5 вересня 2017 року № 2145-VIII. URL: https://zakon.rada.gov.ua/laws/show/2145-19/print].

8. Стельмах А.Г. Активізація діяльності Ради освітнього округу - необхідна умова створення єдиного освітнього простору в межах округу. Управління школою. 2018. №10-12. C. 79-83.

9. Функціонування опорних шкіл: за результатами опитування директорів опорних шкіл. URL: https://iea.gov.ua/wp-content/uploads/2017/12/1.pdf

10. Хоцька Л.М. Шляхи модернізації управління в освітніх округах району. Управління школою. 2018. №10-12. С. 84-87.

11. http://school22.rv.ua/положення-про-діяльність

12. http://school3.ck.ua/polozhennya-pro-radu-shkoli/

13. https://kirschool30.kirovedu.com/uk/site/polozhennya-pro-batkivski.html

14. https://nedrschool.com.ua/site/page?id=67

\section{References:}

1. Verbylo L.V. Denyshevskyi osvitnii okruh - shkola liudynotvorennia. Zavuchu. Use dlia roboty. 2016. №3-4. S. 22-23-22-27

2. Volchenko L. Model upravlinnia hromadsko-aktyvnoiu shkoloiu. Derzhavnohromadske upravlinnia shkoloiu / uporiad. M.K. Holubenko. Kyiv: Shk. svit.2010. S. 23-35. (Biblioteka «Shkilnoho svitu»). 
3. Ielnykova H. Metodolohichni zasady derzhavno-hromadskoho upravlinnia zahalnoiu serednoiu osvitoiu. Derzhavno-hromadske upravlinnia shkoloiu / uporiad. M.K. Holubenko. Kyiv: Shk. svit.2010. S. 5-17. (Biblioteka «Shkilnoho svitu»).

4. Klymko L.V. Rozbudova rehionalnoi merezhi hromadsko-aktyvnykh shkil za umov osvitnikh zmin. Upravlinnia shkoloiu. 2018. №13-15. S. 20-24.

5. Melnychuk L.S. Shkola yak oseredok rozvytku hromady. Upravlinnia shkoloiu. 2018. №10-12. S. 73-78

6. Pro zatverdzhennia Polozhennia pro osvitnii okruhi opornyi zaklad osvity: postanova Kab. Ministriv Ukrainy vid 19 chervnia 2019 r. № 532. URL:https://zakon.rada.gov.ua/laws/show/532-2019-\%D0\%BF\#n78.

7. Pro osvitu: Zakon Ukrainy vid 5 veresnia 2017 roku № 2145-VIII. URL: https://zakon.rada.gov.ua/laws/show/2145-19/print].

8. Stelmakh A.H. Aktyvizatsiia diialnosti Rady osvitnoho okruhu - neobkhidna umova stvorennia yedynoho osvitnoho prostoru v mezhakh okruhu. Upravlinnia shkoloiu. 2018. №10-12. S. 79-83.

9. Funktsionuvannia opornykh shkil: za rezultatamy opytuvannia dyrektoriv opornykh shkil. URL: https://iea.gov.ua/wp-content/uploads/2017/12/1.pdf

10. Khotska L.M. Shliakhy modernizatsii upravlinnia $v$ osvitnikh okruhakh raionu. Upravlinnia shkoloiu. 2018. №10-12. S. 84-87.

11. http://school22.rv.ua/polozhennia-pro-diialnist

12. http://school3.ck.ua/polozhennya-pro-radu-shkoli/

13. https://kirschool30.kirovedu.com/uk/site/polozhennya-pro-batkivski.html

14. https://nedrschool.com.ua/site/page?id=67 